\title{
EVALUASI KETERCAPAIAN STANDAR ISI PERKEMBANGAN \\ NILAI-NILAI AGAMA DAN MORAL ANAK USIA DINI PADA SEMESTER GASSAL 2016/2017 KB/TK PEDAGOGIA
}

\author{
Oleh: \\ Amir Syamsudin \\ paud/pgpaud fip uny. \\ amir_symsdn̄ $\bar{n}$ yahoo.com.; amir_syamsudin̄ uny.ac.id.
}

\begin{abstract}
Abstrak
Tujuan dari penelitian ini adalah mengevaluasi ketercapaian indikator-indikator teoretik nilainilai agama dan moral anak usia dini yang diekpresikan anak dalam perilaku selama proses pembelajaran. Langkah-langkah penelitian meliputi kajian literatur, menyusun kerangka konseptual hubungan antara substansi dan perkembangan nilai-nilai agama dan moral anak usia dini, menyusun definisi operasional, merumuskan indikator perkembangan nilai-nilai agama dan moral anak usia dini, menyusun draft model faktorial nilai-nilai agama dan moral beserta seluruh indikator teoretiknya, pengumpulan data penelitian, dan analisis data menggunakan confirmatory factor analyses. Subjek penelitian berjumlah 71 anak dari rentang usia 3-6 tahun. Hasil penelitian menemukan 27 indikator perkembangan NAM anak usia 5-6 tahun, 20 indikator untuk anak usia 4-5 tahun, dan 10 indikator untuk anak usia 3-4 tahun telah dikukuhkan oleh data empirik.
\end{abstract}

Kata kunci: perkembangan, nilai agama dan moral, anak usia dini.

Abstract
The research objective is to evaluate theoretical achievement indicators of religious and moral values of early childhood expressed in behavior during the learning process. Research steps include review of the literature, preparing the conceptual framework of the relationship between the substance and the development of early childhood religious and moral values, preparing an operational definition, assemble indicator for the development of early childhood religious and moral values, drafting models factorial for religious and moral values, data collection, and data analysis using confirmatory factor analyzes. Respondents were 71 children from ages 3-6 years. Results of the study were 27 indicators of child development for religious and moral values aged 5-6 years, 20 indicators for children aged 4-5 years, and 10 indicators for children aged 3-4 years have been confirmed by empirical data.

Keywords: development, religious values and moral, early childhood.

PENDAHULUAN

Agama merupakan fakta sejarah yang sama tuanya dengan sejarah manusia. Tidak sedikit ilmuwan yang sudah mendefinisikan agama, namun definisi tersebut tidak selalu mencakup semua gejala agama. Kelemahan utama dari pendefinisian agama ialah subjektivitas dari perumus definisi agama itu sendiri. Unsur pengalaman dan bacaan perumus definisi selalu menyeruak masuk ke dalam definisi yang dibuatnya sehingga tidak dapat memuaskan semua orang.

Ada dua pendekatan dalam mendefinisikan agama, yaitu pendekatan substantif dan pendekatan fungsional (Jalaludin Rakhmat, 2003; Lickona, 1992). Pendekatan substantif lebih menekankan apa itu agama, sedangkan pendekatan fungsional lebih menekankan apa guna agama bagi pemeluknya. Pendekatan substantif menyebut agama identik dengan Tuhan yang maha suci, sedangkan pendekatan fungsional menyebut agama sebagai ruang bagi ekspresi manusia untuk menyatukan atau memecah belah umat manusia.

Dimensi fungsi agama ada yang bersifat individual dan sosial sama seperti dimensi substansi agama juga ada yang 
bersifat individual dan sosial. Oleh karena itu ada empat pola definisi agama, yaitu personal fungsional, personal substansial, sosial fungsional, dan sosial substansial (Koentjaraningrat, 1986; Koentjaraningrat, 1987). Definisi agama memakai pola personal fungsional menjadi agama sebagai pemenuhan tujuan spiritual individu, pola personal substansial menjadi agama sebagai kesadaran personal tentang yang sakral, pola sosial fungsional menjadi agama sebagai pemersatu atau pemecah belah masyarakat, dan pola sosial substansial menjadi agama sebagai kesepakatan bersama tentang doktrin agama.

Pola definisi agama yang cocok untuk anak usia dini adalah personal fungsional, yaitu anak memenuhi rasa ingin tahunya tentang yang gaib melalui apa yang bermanfaat atau berbahaya bagi dirinya melalui pengalaman langsung. Berdasarkan pengalaman langsung itulah anak-anak akan mengenal dan menghayati perilaku positif yang bersumber dari ajaran agama yang dianutnya. Untuk mengobservasi pengalaman langsung mempraktikan nilainilai agama dalam proses pembelajaran, maka diperlukan indikator-indikator perilaku yang handal, baik secara teoretik maupun empirik. Tujuan dari penelitian ini adalah mengonfirmasi indikator-indikator teoretik tersebut dengan data-data empirik perkembangan nilai-nilai agama dan moral yang diekpresikan anak dalam perilakunya selama proses pembelajaran.

\section{METODE PENELITIAN}

Penelitian ini merupakan penelitian dasar tentang indikator perkembangan nilai-nilai agama dan moral anak usia dini. Jenis penelitian ini merupakan penelitian kuantitatif.

\section{Jenis Penelitian}

Penelitian ini menggunakan pendekatan kuantitatif, yaitu merumuskan indikator teoretik perkembangan nilai-nilai agama dan moral anak usia 3-6 tahun dari literatur. Hasil rumusan teoretik diujikan dengan cara mengamati perilaku anak yang mengindikasikan perkembangan nilai-nilai agama dan moral. Hasil pengujian tersebut menghasilkan indikator teoretik yang dikuatkan (confirmatory) oleh data empirik perkembangan nilai-nilai agama dan moran anak usia dini, tetapi sebaliknya ada juga yang tidak didukung oleh data lapangan sehingga dikeluarkan dari anggota kelompok faktor perkembangan NAM.

\section{Waktu dan Tempat Penelitian}

Lokasi penelitian ada di wilayah kota Yogyakarta. Waktu penelitian mulai bulan April sampai dengan Oktober 2016. Metode pengumpulan data dengan observasi perilaku anak yang bersinggungan dengan nilai-nilai agama dan moral selama proses pembelajaran sejak anak datang ke sekolah sampai pulang dari sekolah. Instrumen pengambilan data berupa lembar observasi yang diisi oleh petugas pengumpul data. Petugas pengumpul data adalah peneliti sebanyak 4 orang yang terdiri satu orang dosen dan tiga orang mahasiswa PAUD.

\section{Subjek Penelitian}

Subjek yang diteliti adalah anak usia 3-6 tahun di TK Pedagogia Jl. Bantul 50 Yogyakarta sebanyak 71 orang anak. Subjek terdiri dari Kelompok Bermain usia 3-4 tahun sejumlah 9 anak, Taman Kanakkanak kelompok usia 4-5 tahun sejumlah 29 anak, dan Taman Kanak-kanak kelompok usia 5-6 tahun sejumlah 33 anak. Prosedur

Langkah-langkah penelitiannya meliputi kajian literatur tentang substansi nilai-nilai agama dan moral, kajian literatur tentang perkembangan keagamaan anak usia dini, menyusun kerangka konseptual hubungan antara substansi dan perkembangan nilai-nilai agama dan moral anak usia dini, menyusun definisi operasional, merumuskan indikator perkembangan nilai-nilai agama dan moral anak usia dini, menyusun draft model faktorial nilai-nilai agama dan moral beserta seluruh indikator teoretiknya, validasi instrumen oleh ahli nilai-nilai agama dan moral, pengumpulan data penelitian, tabulasi data, praanalisis data sehingga siap dianalisis, dan terakhir 
analisis data menggunakan confirmatory factor analyses serta pelaporan penelitian.

\section{Data, Intrumen, dan Teknik Pengumpulan Data}

Data yang dikumpulkan merupakan data rasio tentang perkembangan nilai-nilai agama dan moral anak usia dini. Instrumen pengumpulan data menggunakan lembar observasi perkembangan anak yang terdiri dari rentang skor 1 sampai dengan 40 . Teknik pengumpulan data dengan cara mengisi lembar observasi yang berisi indikator perkembangan nilai-nilai agama dan moral secara teoretik. Pengisi lembar observasi adalah peneliti sendiri dan guru PAUD.

\section{Teknik Analisis Data}

Teknik analisis data menggunakan confirmatory factor analyis (CFA). Jenis data yang dikumpulkan adalah data kuantitatif tentang perilaku anak yang mengindikasikan perkembangan nilai-nilai agama dan moral anak usia dini. Tabulasi data kuantitatif, praanalisis data, penggunaan CFA, dan penafsiran data (Santoso, 2014).

\section{HASIL PENELITIAN DAN PEMBAHASAN}

Pengambilan data penelitian dilaksanakan mulai tanggal 09-20 Agustus 2016. Ada dua cara pengambilan data, yaitu pertama observasi langsung proses pembelajaran, dan kedua persepsi guru tentang perkembangan NAM anak selama interaksi pembelajaran 14 hari kerja. Kedua data ini saling melengkapi dan mengoreksi rekaman observasi langsung dan persepsi guru tentang perkembangan NAM anak.

Subjek yang dilteliti terdiri dari kelompok anak usia 5-6, usia 4-5, dan usia 3-4 tahun di TK/KB Pedagogia FIP UNY. Jumlah anak yang menjadi partisipan penelitian sebanyak 71 anak. Data perkembangan NAM anak yang diolah sebanyak 63 anak, sedangkan data perkembangan NAM 8 anak berkebutuhan khusus tidak dianalisis karena banyak indikator NAM yang belum muncul.

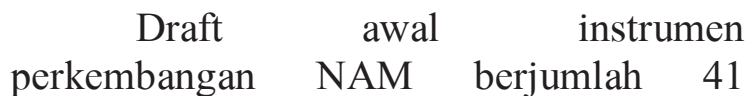
indikator untuk kelompok anak usia 5-6 tahun, 20 indikator untuk kelompok usia 45 tahun, dan 10 indikator untuk kelompok anak usia 3-4 tahun. Indikator perkembangan NAM untuk kelompok usia 5-6 tahun dikelompokkann ke dalam 4 faktor, yaitu berdo'a sebanyak 5 indikator, kebersihan diri sebanyak 6 indikator, interaksi dalam proses pembelajaran sebanyak 14 indikator, dan pengetahuan/praktik ibadah sebanyak 5 indikator (Menteri Pendidikan \& Kebudayaan RI, 2014, Nomor 137 dan 146; Peraturan Menteri Pendidikan Nasional Nomor 58 Tahun, 2009; Lickona, 1992).

Indikator perkembangan NAM untuk usia 4-5 tahun dikelompokkan ke dalam 2 faktor, yaitu berdo'a sebanyak 9 indikator, dan faktor interaksi dalam proses pembelajaran sebanyak 11 indikator. Indikator perkembangan NAM untuk usia 3-4 tahun dikelompokkan ke dalam 2 faktor, yaitu berdo'a sebanyak 3 indikator, dan interaksi proses pembelajaran sebanyak 7 indikator.

Proses analisis faktorial ekploratif meliputi menilai variabel yang layak untuk dianalisis, proses faktorial dan rotasi, validasi analisisi faktor, dan pembuatan faktor skor (Singgih Santoso, 2014). Dalam penelitian ini, analisis faktor hanya dilakukan untuk tahap satu dan tahap dua, karena tahap tiga dan tahap empat dapat dilakukan jika untuk generalisasi dari sample faktorial ke populasi faktorial. Subjek dalam penelitian ini sebanyak 63 anak diteliti semua, sehingga cukup analisis faktorial eksploratif tahap satu dan tahap dua saja. Tahap pertama menilai variabel yang layak dianalisis untuk kelompok anak usia 5-6 tahun, 4-5 tahun, dan 3-4 tahun secara berurutan dan tahap kedua proses faktorial, rotasi, dan penamaan akhir untuk masing-masing faktor.

\section{Penilaian Kelayakan Variabel}

Ada 4 faktor teoritik perkembangan NAM anak usia 5-6 tahun, yaitu do'a, bersih diri, interaksi dalam proses 
pembelajaran, dan pengetahuan/praktik ibadah (mengenal tempat ibadah, mengenal nama hari besar agama, dan mengenal tokoh-tokoh agama).

Faktor do'a terdiri dari 5 indikator dan hasil analisis kelayakan variabel diukur berdasarakan angka KMO and Bartlett's test lebih besar dari 0,50 dengan signifikansi dibawah 0,05 dan Anti-image untuk skor Measures of Sampling Adequacy (MSA) lebih besar dari 0,50. Skor KMO and Bartlett's test lebih besar dari $0,5\left(0,82^{-} 0,50\right)$ dengan skor signifikansi lebih kecil dari $0,05(0,000$ $0,05)$ sebagai kriteria kelayakan analisis lanjut faktorial.

Berdasarkan dua kriteria tersebut dapat disimpulkan bahwa faktor berdo'a yang berisi 5 indikator dapat dianalisis lebih. Skor MSA sama dengan atau lebih besar dari 0,51 berarti indikator layak menjadi anggota faktor, sebaliknya apabila skor MSA sama dengan atau lebih kecil dari 0,50 berarti tidak layak menjadi anggota faktor. Skor MSA indikator mengucapkan syukur jika diberi guru sebesar 0,78. Skor MSA indikator mengucapkan syukur jika diberi teman sebesar 0,76. Skor MSA indikator mengucapkan pujian kepada Tuhan sebesar 0,84 .

Skor MSA indikator mengucapkan do'a pasrah terhadap musibah sebesar 0,88 . Skor MSA indikator mengucapkan do'a ampunan atas kesalahan sebesar 0,90. Kelima indikator tersebut memiliki skor MSA lebih dari 0,50 sehingga dapat disimpulkan kelima indikator layak menjadi anggota faktor berdo'a.

Faktor bersih diri terdiri dari 6 indikator dan hasil analisis kelayakan variabel diukur berdasarakan angka $K M O$ and Bartlett's test lebih besar dari 0,50 dengan signifikansi dibawah 0,05 dan Antiimage untuk skor Measures of Sampling Adequacy (MSA) lebih besar dari 0,50. Skor KMO and Bartlett's test lebih besar dari $0,5\left(0,70^{-} \quad 0,50\right)$ dengan skor signifikansi lebih kecil dari $0,05(0,000$ $0,05)$ sebagai kriteria kelayakan analisis lanjut faktorial. Berdasarkan dua kriteria tersebut dapat disimpulkan bahwa faktor bersih diri yang berisi 6 indikator dapat dianalisis lebih lanjut.

Skor MSA sama dengan atau lebih besar dari 0,51 berarti indikator layak menjadi anggota faktor, sebaliknya apabila skor MSA sama dengan atau lebih kecil dari 0,50 berarti tidak layak menjadi anggota faktor. Skor MSA indikator berpakaian bersih sebesar 0,88. Skor MSA indikator frekuensi latihan gosok gigi sebesar 0,68. Skor MSA indikator frekuensi latihan cuci tangan sebesar 0,85 . Skor MSA indikator latihan buang sampah pada tempatnya sebesar 0,69. Skor MSA indikator latihan membersihkan bekas buang air kecil sebesar 0,64. Skor MSA indikator latihan membersihkan bekas buang air besar sebesar 0,60. Keenam indikator tersebut memiliki skor MSA lebih dari 0,50 sehingga dapat disimpulkan keenam indikator layak menjadi anggota faktor bersih diri.

Faktor proses interaksi dalam pembelajaran terdiri dari 14 indikator dan hasil analisis kelayakan variabel diukur berdasarakan angka KMO and Bartlett's test lebih besar dari 0,50 dengan signifikansi dibawah 0,05 dan Anti-image untuk skor Measures of Sampling Adequacy (MSA) lebih besar dari 0,50. Skor KMO sebesar 0,65 pada tahap pertama dengan jumlah indikator sebanyak 14 indikator, 0,71 pada tahap kedua dengan jumlah indikator sebanyak 13 indikator (karena ada 1 indikator tidak layak dianalisis lebih lanjut), 0,73 pada tahap ketiga dengan jumlah indikator sebanyak 12 indikator (karena ada 2 indikator tidak layak dianalisis lebih lanjut), dan 0,76 pada tahap keempat dengan jumlah indikator sebanyak 11 indikator (karena ada 3 indikator tidak layak dianalisis lebih lanjut).

Hasil analisis tahap keempat, skor KMO 0,76 lebih besar dari 0,50 sebagai kriteria menolak atau menerima indikator menjadi anggota faktor dengan signifikansi 0,000 dan jauh lebih kecil dari 0,05 sebagai 
kriteria maksimum kelayakan analisis lanjut faktorial. Berdasarkan dua kriteria tersebut dapat disimpulkan bahwa faktor proses interaksi pembelajaran yang semula berisi 14 indikator berubah menjadi 11 indikator yang dapat dianalisis lebih lanjut setelah empat kali analisis. Skor KMO and Bartlett's test lebih besar dari 0,5 $\left(0,763^{-}\right.$ $0,50)$ dengan skor signifikansi lebih kecil dari $0,05(0,00 \overline{0} \quad 0,05)$ sehingga kesebelas indikator dapat dianalisis lebih lanjut.

Skor MSA sama dengan atau lebih besar dari 0,51 berarti indikator layak menjadi anggota faktor, sebaliknya apabila skor MSA sama dengan atau lebih kecil dari 0,50 berarti tidak layak menjadi anggota faktor. Skor MSA indikator berucap terima kasih sebesar 0,63. Skor MSA indikator berucap mohon maaf sebesar 0,75. Skor MSA indikator membalas sapaan teman sebesar 0,74. Skor MSA indikator membalas sapaan guru sebesar 0,73. Skor MSA indikator menyapa teman pada saat awal bertemu sebesar 0,80. Skor MSA indikator menyapa teman saat berpisah sebesar 0,78. Skor MSA indikator menyapa guru pada saat awal bertemu sebesar 0,80. Skor MSA indikator menyapa guru saat berpisah sebesar 0,77. Skor MSA indikator mentaati aturan kelompok sebesar 0,86 . Skor MSA indikator anak membantu guru di luar kelas sebesar 0,70. Skor MSA indikator membantu teman di luar kelas sebesar 0.70 .

Kesebelas indikator tersebut memiliki skor MSA lebih besar dari 0,50 sehingga dapat disimpulkan kesebelas indikator layak menjadi anggota faktor interaksi pembelajaran.

Faktor pengetahuan nilai-nilai agama dan praktik ibadah terdiri dari lima indikator, yaitu praktik ibadah 1, praktik ibadah 2, mengenal tempat ibadah, mengenal hari besar agama, dan mengenal tokoh-tokoh agama. Kelima indikator tersebut telah memenuhi kriteria analisis lanjut faktor, karena skor $K M O$ and Bartlett's test lebih besar dari 0,5 $\left(0,77^{-}\right.$ $0,50)$ dengan skor signifikansi lebih kecil dari $0,05(0,00 \overline{3} \quad 0,05)$.
Skor MSA indikator praktik 1 sebesar 0,797, skor MSA indikator praktik 2 sebesar 0,741, skor MSA indikator mengenal tempat ibadah sebesar 0,783, skor MSA indikator mengenal hari besar agama sebesar 0,805, dan skor MSA indikator mengenal cerita tokoh-tokoh agama sebesar 0,787. Kelima indikator tersebut memiliki skor MSA lebih besar dari 0,50 sehingga dapat disimpulkan kelima indikator layak menjadi anggota faktor pengetahuan nilai-nilai agama.

Ada dua faktor NAM yang terbentuk secara teoritik untuk kelompok anak usia 4-5 tahun, yaitu faktor berdo'a dan faktor interaksi pembelajaran. Berikut uraian faktor analisis confirmatory untuk kedua faktor teoritik tersebut.

Faktor do'a terdiri dari 9 indikator dan hasil analisis kelayakan variabel diukur berdasarakan angka KMO and Bartlett's test lebih besar dari 0,50 dengan signifikansi dibawah 0,05 dan Anti-image untuk skor Measures of Sampling Adequacy (MSA) lebih besar dari 0,50.

Kesembilan indikator tersebut telah memenuhi kriteria analisis lanjut faktor, karena skor KMO and Bartlett's test lebih besar dari $0,5\left(0,73^{-} 0,50\right)$ dengan skor signifikansi lebih kecil dari $0,05(0,000$ $0,05)$ seperti terdapat pada Tabel 10. Berdasarkan dua kriteria tersebut dapat disimpulkan bahwa faktor berdo'a yang berisi 9 indikator dapat dianalisis lebih lanjut.

Skor MSA sama dengan atau lebih besar dari 0,51 berarti indikator layak menjadi anggota faktor, sebaliknya apabila skor MSA sama dengan atau lebih kecil dari 0,50 berarti tidak layak menjadi anggota faktor. Skor MSA indikator do'a syukur diberi guru sebesar 0.784, do'a syukur diberi teman sebesar 0.745 , pujian kepada Tuhan sebesar 0.764, do'a pasrah terhadap musibah sebesar 0.737, do'a ampunan atas kesalahan sebesar 0.883, do'a pendek sebelum belajar sebesar 0.550 , do'a pendek setelah belajar sebesar 0.726 , do'a pendek sebelum makan sebesar 0.610, dan do'a pendek setelah makan sebesar 
0.714. Kesembilan indikator tersebut memiliki skor MSA lebih besar dari 0,50 sehingga dapat disimpulkan kesembilan indikator layak menjadi anggota faktor berdo'a.

Faktor interaksi pembelajaran terdiri dari 11 indikator dan hasil analisis kelayakan variabel diukur berdasarakan angka KMO and Bartlett's test lebih besar dari 0,50 dengan signifikansi dibawah 0,05 dan Anti-image untuk skor Measures of Sampling Adequacy (MSA) lebih besar dari 0,50. Kesebelas indikator tersebut telah memenuhi kriteria analisis lanjut faktor, karena skor KMO and Bartlett's test lebih besar dari $0,5\left(0.826^{-} \quad 0,50\right)$ dengan skor signifikansi lebih kecil dari $0,05\left(0,000{ }^{-}\right.$ 0,05). Berdasarkan dua kriteria tersebut dapat disimpulkan bahwa faktor interaksi pembelajaran yang berisi 11 indikator dapat dianalisis lebih lanjut.

Skor MSA sama dengan atau lebih besar dari 0,51 berarti indikator layak menjadi anggota faktor, sebaliknya apabila skor MSA sama dengan atau lebih kecil dari 0,50 berarti tidak layak menjadi anggota faktor. Skor MSA indikator membantu teman sebesar 0.840, membantu guru sebesar 0.828 , berucap terima kasih sebesar 0.834 , berucap mohon maaf sebesar 0.867, balas sapaan teman sebesar 0.828, balas sapaan guru sebesar 0.842, sapa teman awal temu sebesar 0.807 , sapa teman berpisah sebesar 0.825 , sapa guru awal temu sebesar 0.826, sapa guru berpisah sebesar 0.783 , dan praktik 1 sebesar 0.801 . Kesebelas indikator tersebut memiliki skor MSA lebih besar dari 0,50 sehingga dapat disimpulkan kesebelas indikator layak menjadi anggota faktor interaksi pembelajaran.

Data kelompok anak usia 3-4 tahun tidak dapat dianalisis faktorial konfirmatori karena jumlah subjek yang diteliti hanya 9 orang. Oleh karena itu untuk proses factorial tidak dapat dilakukan. Namun dari hasil observasi langsung proses pembelajaran kesepuluh indikator teoritik muncul pada perilaku anak. Kesepuluh indikator tersebut terbagi ke dalam dua kelompok faktor, yaitu faktor berdo'a memiliki 3 indikator (berdo'a sebelum belajar, setelah belajar, dan sebelum makan), dan faktor interaksi proses pembelajaran memiliki 7 indikator (berbagi makanan, alat mainan, membantu teman, menyapa guru, menyapa teman, berpakaian bersih, dan mencuci tangan).

\section{Analisis Faktorial}

Tahap kedua dari analisis faktor ialah membuat faktor dengan cara menganalisis data communalities, skor eigenvalues, scree plot, component matrix, dan rotasi matrix. Uraian lengkap proses analisis tersebut dinarasikan sebagai berikut.

Ada 4 faktor untuk kelompok anak usia 5-6 tahun, yaitu faktor do'a, kebersihan diri, interaksi proses pembelajaran, dan pengetahuan/praktik nilai-nilai agama dan moral sebagaimana terinci berikut ini.

Faktor berdo'a memiliki 5 indikator. Indikator berdo'a syukur ketika diberi guru memperoleh skor communalities sebesar 0.681. Indikator berdo'a syukur ketika diberi teman memperoleh skor communalities sebesar 0.877. Indikator mengucapkan pujian kepada Tuhan ketika melihat peristiwa alam maupun sosial, memperoleh skor communalities sebesar 0.823. Indikator berdo'a pasrah ketika mendapatkan musibah, memperoleh skor communalities sebesar 0.540. Indikator berdo'a meminta ampunan atas segala kesalahan memperoleh skor communalities sebesar 0.618. Kelima indikator tersebut memiliki skor communalities lebih besar dari 0.50 dan hal ini berarti masing-masing indikator memenuhi syarat untuk dimasukkan sebagai anggota faktor berdo'a.

Ada lima komponen varians dari faktor berdo'a. Apabila varians komponen 1 sampai dengan komponen 5 dijumlahkan, maka hasilnya sama dengan 5 (3.539 + $0.701+0.525+0.191+0.044=5)$. Total variansnya juga berjumlah 5 , yaitu dari 5 komponen dikalikan total varians dari masing-masing komponen, yaitu 1 
sehingga prosesnya menjadi $5 \times 1$. Komponen 1 memiliki skor Eigenvalues lebih besar dari 1 (3.539), sedangkan komponen 2, 3, 4, dan 5 memiliki skor Eigenvalues lebih kecil dari 1 (0.701, $0.525,0.191$, dan 0.044) maka proses factoring sudah selesai.

Dengan demikian, faktor berdo'a berisi 5 indikator, yaitu berdo'a syukur ketika diberi sesuatu oleh guru, berdo'a syukur ketika diberi sesuatu oleh teman, mengucapkan pujian kepada Tuhan ketika melihat peristiwa alam atau peristiwa sosial, berdo'a pasrah kepada Tuhan ketika mendapatkan musibah, dan berdo'a memohon ampunan atas segala kesalahan diri sendiri.

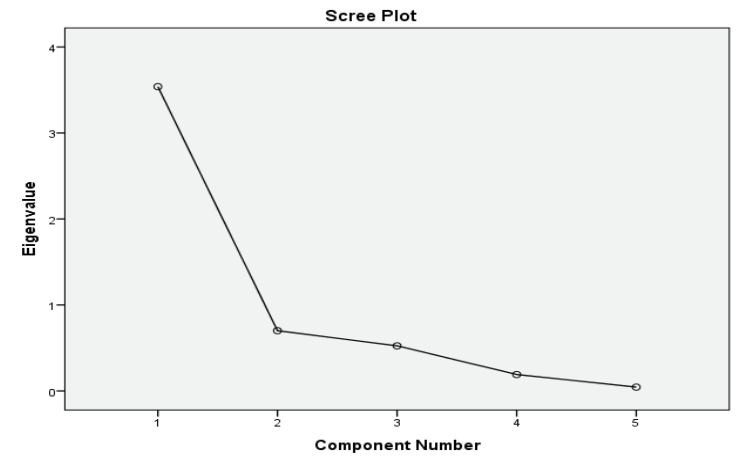

Gambar 1.

Garis Sumbu Component Number 1-5 Faktor Berdo'a Anak Usia 5-6 Tahun

Terlihat bahwa dari garis sumbu component number 1 ke 2 menurun tajam, tetapi dari komponen 2 ke 3, 3 ke 4, dan 4 ke 5 garis sumbu component number menurun landai. Skor Eigenvalues komponen 2, 3, 4, dan 5 juga berada di bawah skor Eigenvalues 1 seperti pada Gambar 1. Hal ini menunjukkan bahwa kelima indikator dapat dikumpulkan ke dalam 1 faktor saja, yaitu faktor yang diberi nama "berdo'a".

Angka factor loading sebesar 0.55 merupakan cut off penerimaan indikator sebagai anggota faktor. Angka factor loading indikator berdo'a syukur ketika diberi sesuatu oleh guru sebesar 0.825. Angka factor loading indikator berdo'a syukur ketika diberi sesuatu oleh teman sebesar 0.936. Angka factor loading indikator mengucapkan pujian kepada Tuhan ketika melihat peristiwa alam atau peristiwa sosial sebesar 0.907. Angka factor loading indikator berdo'a pasrah ketika mendapatkan musibah sebesar 0.735 . Angka factor loading indikator berdo'a memohon ampunan atas segala kesalahan sebesar 0.786. Kelima angka factor loading masing-masing indikator lebih besar dari skor $0.55(0.825,0.936,0.907,0.735$, dan 0.786) sehingga dapat disimpulkan bahwa faktor berdo'a yang terdiri dari lima indikator sudah mewakili perilaku nilainilai agama dari anak usia dini 5-6 tahun.

Faktor kebersihan diri memiliki 6 indikator. Indikator pakaian bersih memperoleh skor communalities sebesar 0.641. Indikator gosok gigi memperoleh skor communalities sebesar 0.755 . Indikator cuci tangan memperoleh skor communalities sebesar 0.659. Indikator buang sampah pada tempatnya memperoleh skor communalities sebesar 0.789. Indikator membersihkan bekas BAK memperoleh skor communalities sebesar 0.655. Indikator membersihkan bekas BAB memperoleh skor communalities sebesar 0.725 . Keenam indikator tersebut memiliki skor communalities lebih besar dari 0.50 dan hal ini berarti masing-masing indikator memenuhi syarat untuk dimasukkan sebagai anggota faktor kebersihan diri.

Ada enam komponen varians dari faktor kebersihan diri. Apabila varians komponen 1 sampai dengan komponen 6 dijumlahkan, maka hasilnya sama dengan 6 $(4.223+0.931+0.400+0.228+0.177+$ $0.042=6$ ). Total variansnya juga berjumlah 6, yaitu dari 6 komponen dikalikan total varians dari masing-masing komponen, yaitu 1 sehingga prosesnya menjadi $6 \times 1$. Komponen 1 memiliki skor Eigenvalues lebih besar dari 1 (4.223), sedangkan komponen 2, 3, 4, 5, dan 6 memiliki skor Eigenvalues lebih kecil dari 1 (0.931, $0.400,0.228,0.177$, dan 0.042) maka proses factoring sudah selesai. Dengan demikian, faktor Kebersihan Diri berisi 6 indikator, yaitu pakaian bersih, gosok gigi, cuci tangan, buang sampah pada 
tempatnya, bersihkan bekas BAK, dan bersihkan bekas BAB.

Terlihat bahwa dari garis sumbu component number 1 ke 2 menurun tajam, tetapi dari komponen 2 ke 3, 3 ke 4, 4 ke 5, dan 5 ke 6 garis sumbu component number menurun landai. Skor Eigenvalues komponen 2, 3, 4, 5, dan 6 juga berada di bawah skor Eigenvalues 1 seperti pada Gambar 2. Hal ini menunjukkan bahwa keenam indikator dapat dikumpulkan ke dalam 1 faktor saja, yaitu faktor yang diberi nama "Kebersihan Diri".

Angka factor loading sebesar 0.550 merupakan cut off penerimaan indikator sebagai anggota faktor. Angka factor loading indikator pakaian bersih sebesar 0.800. Angka factor loading indikator gosok gigi sebesar 0.869. Angka factor loading indikator cuci tangan sebesar 0.812. Angka factor loading indikator buang sampah pada tempatnya sebesar 0.888. Angka factor loading indikator membersihkan bekas buang air kecil sebesar 0.809. Angka factor loading indikator membersihkan bekas buang air besar sebesar 0.852 .

Keenam angka factor loading masing-masing indikator lebih besar dari skor $0.550(0.800,0.869,0.812,0.888$, 0.809 , dan 0.852) sehingga dapat disimpulkan bahwa faktor kebersihan diri yang terdiri dari enam indikator sudah mewakili perilaku nilai-nilai agama dari anak usia dini 5-6 tahun.

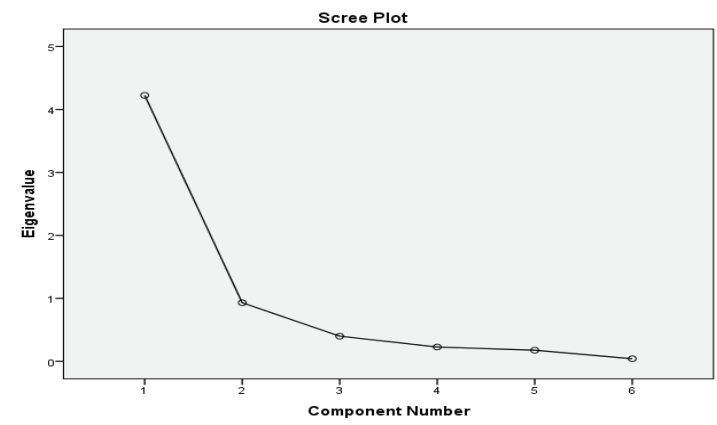

Gambar 2.

Garis Sumbu Component Number 1-6 Faktor Kebersihan Diri Anak Usia 5-6 Tahun
Faktor interaksi pembelajaran memiliki 11 indikator. Indikator berucap terima kasih memperoleh skor communalities sebesar 0.835. Indikator berucap mohon maaf memperoleh skor communalities sebesar 0.776. Indikator membalas sapaan teman memperoleh skor communalities sebesar 0.717. Indikator membalas sapaan guru memperoleh skor communalities sebesar 0.830. Indikator menyapa teman pada saat awal bertemu memperoleh skor communalities sebesar 0.851. Indikator menyapa teman saat berpisah memperoleh skor communalities sebesar 0.842. Indikator menyapa guru pada saat awal bertemu memperoleh skor communalities sebesar 0.828. Indikator menyapa guru saat berpisah memperoleh skor communalities sebesar 0.894 . Indikator mentaati aturan kelompok memperoleh skor communalities sebesar 0.741. Indikator membantu guru di luar kelas memperoleh skor communalities sebesar 0.894. Indikator membantu teman di luar kelas memperoleh skor communalities sebesar 0.884. Kesebelas indikator tersebut memiliki skor communalities lebih besar dari 0.50 dan hal ini berarti masing-masing indikator memenuhi syarat untuk dimasukkan sebagai anggota faktor kebersihan diri.

Ada sebelas komponen varians dari faktor interaksi pembelajaran. Apabila varians komponen 1 sampai dengan komponen 11 dijumlahkan, maka hasilnya sama dengan $11(6.127+1.736+1.229+$ $0.578+0.424+0.349+0.226+0.144+$ $0.093+0.055+0.037=11)$. Total variansnya juga berjumlah 11 , yaitu dari 11 komponen dikalikan total varians dari masing-masing komponen, yaitu 1 sehingga prosesnya menjadi $11 \times 1$. Komponen 1, 2, dan 3 memiliki skor Eigenvalues lebih besar dari 1 (6.127, 1.736, 1.229), sedangkan komponen 4, 5, 6, 7, 8, 9, 10, dan 11 memiliki skor Eigenvalues lebih kecil dari 1 (0.578, $0.424,0.349,0.226,0.144,0.093,0.055$, dan 0.037) maka proses factoring sudah selesai. 
Terlihat bahwa dari garis sumbu component number 1 ke 2 menurun tajam, dari 2 ke 3 menurun kurang tajam, dari 3 ke 4 menurun agak landai, tetapi dari komponen 4 ke 5 , dari 5 ke 6 , dari 6 ke 7 , dari 7 ke 8 , dari 8 ke 9, dari 9 ke 10, dan dari 10 ke 11 garis sumbu component number menurun landai. Skor Eigenvalues komponen 1, 2, dan 3 berada di atas skor Eigenvalues 1 . Skor Eigenvalues komponen $4,5,6,7,8,9,10$, dan 11 juga berada di bawah skor Eigenvalues 1 seperti pada Gambar 3. Hal ini menunjukkan bahwa kesebelas indikator dari faktor interaksi pembelajaran dapat dikumpulkan ke dalam 3 sub-faktor, yaitu sub-faktor yang diberi nama "tegur sapa", "disiplin", dan "peduli".

Dengan demikian, faktor interaksi pembelajaran berisi 11 indikator yang terbagi menjadi 3 sub-faktor, yaitu subfaktor tegur sapa dengan 3 indikator, subfaktor disiplin dengan 6 indikator, dan subfaktor peduli dengan 2 indikator.

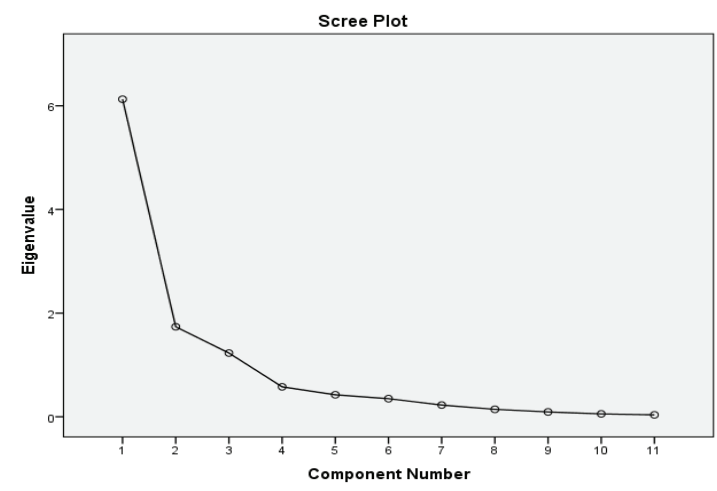

Gambar 3.

Garis Sumbu Component Number 1-11

Faktor Interaksi Pembelajaran

Anak Usia 5-6 Tahun

Angka factor loading sebesar 0.550 merupakan cut off penerimaan indikator sebagai anggota faktor. Sub-faktor tegur sapa terdiri dari indikator membalas sapaan teman dengan skor factor loading sebesar 0.654 .

Indikator membalas sapaan guru dengan skor factor loading sebesar 0.857, menyapa teman saat awal berjumpa dengan skor factor loading sebesar 0.780 , menyapa teman saat berpisah dengan skor factor loading sebesar 0.873 , menyapa guru saat awal berjumpa dengan skor factor loading sebesar 0.851, dan menyapa guru saat berpisah dengan skor factor loading sebesar 0.919 .

Sub-faktor peduli terdiri dari 3 indikator, yaitu menaati aturan kelompok dengan skor factor loading sebesar 0.596, membantu guru di luar kelas dengan skor factor loading sebesar 0.923, dan membantu teman di luar kelas dengan skor factor loading sebesar 0.892. Sedangkan sub-fakor tegur sapa terdiri dari indikator, yaitu mengucapkan terima kasih saat diberi sesuatu oleh orang lain dengan skor factor loading sebesar 0.902, dan mengucapkan mohon maaf saat melakukan kesalahan yang tidak disengaja kepada pihak korban dengan skor factor loading sebesar 0.809.

Berdasarkan data korelasi antara komponen 1 dengan 1, komponen 2 dengan 2, dan komponen 3 dengan 3, dapat disimpulkan bahwa skor korelasi lebih besar dari kriteria minimal, yaitu 0.5. Komponen 1 dengan 1 sama dengan 0.804

0.5 , komponen 2 dengan 2 sama dengan $0.611^{-} \quad 0.5$ meskipun berkorelasi negatif, komponen 3 dengan 3 sama dengan $0.510^{-}$

0.5 . Hal ini membuktikan ketiga sub-faktor sudah terbentuk dengan tepat karena memiliki skor korelasi di atas 0.5.

Sedangkan distribusi indikator mengelompokkan diri pada tiga sub-faktor, yaitu sub-faktor disiplin, sub-faktor peduli, dan sub-faktor tegur sapa seperti pada Gambar 4.

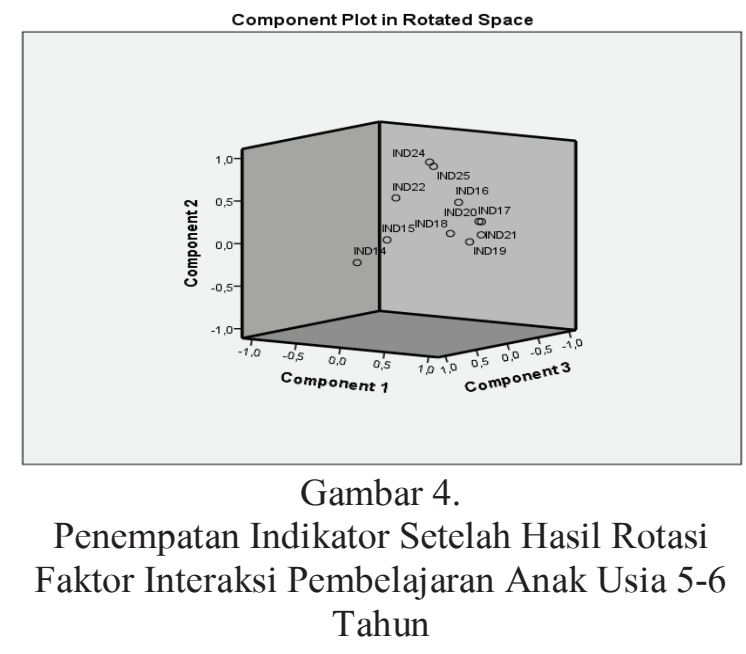


Faktor pengetahuan dan praktik pengamalan nilai-nilai agama dan moral memiliki 5 indikator. Indikator praktik 1 memperoleh skor communalities sebesar 0.456. Indikator praktik 2 memperoleh skor communalities sebesar 0.614. Indikator mengenal tempat ibadah memperoleh skor communalities sebesar 0.542. Indikator mengenal hari besar keagamaan memperoleh skor communalities sebesar 0.457. Indikator mengenal tokoh agama melalui cerita memperoleh skor communalities sebesar 0.411. Dua indikator memiliki skor communalities lebih besar dari 0.50 , yaitu indikator praktik 2 dan mengenal tempat ibadah, sedangkan indikator praktik 1, mengenal hari besar agama, dan mengenal tokoh agama melalui cerita memiliki skor communalities lebih kecil dari 0.50 .

Terlihat bahwa dari garis sumbu component number 1 ke 2 menurun tajam, tetapi dari komponen 2 ke 3, 3 ke 4, dan 4 ke 5 garis sumbu component number menurun landai. Skor Eigenvalues komponen 2, 3, 4, dan 5 juga berada di bawah skor Eigenvalues 1 seperti pada Gambar 5. Hal ini menunjukkan bahwa kelima indikator dapat dikumpulkan ke dalam 1 faktor saja, yaitu faktor yang diberi nama "Pengetahuan/Praktik NAM".

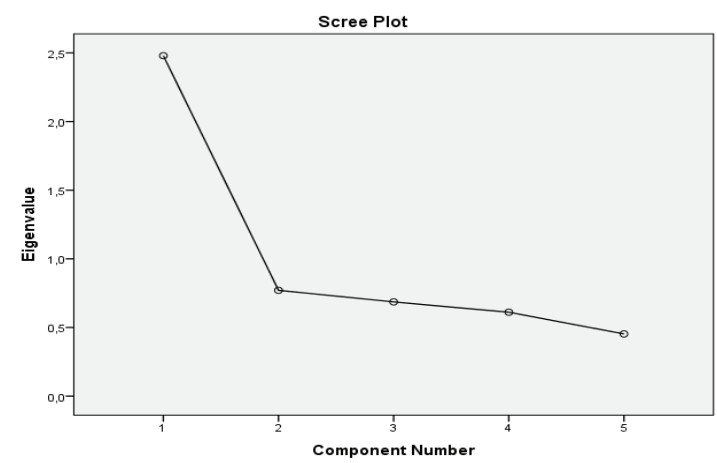

Gambar 5.

Garis Sumbu Component Number 1-5

Faktor Pengetahuan/Praktik NAM Anak Usia 5-6 Tahun

Angka factor loading sebesar 0.550 merupakan cut off penerimaan indikator sebagai anggota faktor. Angka factor loading indikator praktik 1 sebesar 0.675. Angka factor loading indikator praktik 2 sebesar 0.784. Angka factor loading indikator mengenal tempat ibadah sebesar 0.736. Angka factor loading indikator mengenal hari besar keagamaan sebesar 0.676. Angka factor loading indikator mengenal tokoh agama melalui cerita sebesar 0.641. Kelima angka factor loading masing-masing indikator lebih besar dari skor $0.550(0.675,0.784,0.736,0.676$, dan 0.641) sehingga dapat disimpulkan bahwa faktor pengetahuan/praktik NAM yang terdiri dari lima indikator sudah mewakili perilaku nilai-nilai agama dari anak usia dini 5-6 tahun.

Ada dua kelompok faktor indikator perkembangan NAM untuk anak usia 4-5 tahun, yaitu faktor do'a yang memiliki 9 indikator, dan faktor interaksi pembelajaran yang memiliki 11 indikator seperti uraian berikut ini.

Faktor berdo'a memiliki 9 indikator. Indikator berdo'a syukur ketika diberi guru memperoleh skor communalities sebesar 0.896. Indikator berdo'a syukur ketika diberi teman memperoleh skor communalities sebesar 0.931. Indikator mengucapkan pujian kepada Tuhan ketika melihat peristiwa alam maupun sosial memperoleh skor communalities sebesar 0.889. Indikator berdo'a pasrah ketika mendapatkan musibah memperoleh skor communalities sebesar 0.800 . Indikator berdo'a meminta ampunan atas segala kesalahan memperoleh skor communalities sebesar 0.811. Indikator berdo'a sebelum belajar memperoleh skor communalities sebesar 0.960. Indikator berdo'a setelah belajar memperoleh skor communalities sebesar 0.906. Indikator berdo'a sebelum makan memperoleh skor communalities sebesar 0.974. Indikator berdo'a setelah belajar memperoleh skor communalities sebesar 0.872 .

Kesembilan indikator tersebut memiliki skor communalities lebih besar dari 0.50 dan hal ini berarti masing-masing indikator memenuhi syarat untuk dimasukkan sebagai anggota faktor berdo’a. 
Ada sembilan komponen varians dari faktor berdo'a. Apabila varians komponen 1 sampai dengan komponen 9 dijumlahkan, maka hasilnya sama dengan 9 $(6.761+1.277+0.478+0.253+0.152+$ $0.043+0.025+0.007+0.002=9)$. Total variansnya juga berjumlah 9, yaitu dari 9 komponen dikalikan total varians dari masing-masing komponen, yaitu 1 sehingga prosesnya menjadi 9x1. Komponen 1, dan 2 memiliki skor Eigenvalues lebih besar dari 1 (6.761, 1.277), sedangkan komponen 3, 4, 5, 6, 7, 8, dan 9 memiliki skor Eigenvalues lebih kecil dari $1(0.478,0.253,0.152,0.433$, $0.025,0.007$, dan 0.002) maka proses factoring sudah selesai.

Terlihat bahwa dari garis sumbu component number 1 ke 2 menurun tajam, dari 2 ke 3 menurun kurang tajam, tetapi dari komponen 3 ke 4, dari 4 ke 5, dari 5 ke 6 , dari 6 ke 7 , dari 7 ke 8 , dan dari 8 ke 9 garis sumbu component number menurun landai. Skor Eigenvalues komponen 1 dan 2 lebih besar dari 1, sedangkan komponen $3,4,5,6,7,8$, dan 9 berada di bawah skor Eigenvalues 1 seperti pada Gambar 6. Hal ini menunjukkan bahwa kesembilan indikator dapat dikumpulkan ke dalam 2 sub-faktor, yaitu sub-faktor yang diberi nama "berdo'a sebelum kegiatan" dengan 7 indikator dan "berdo'a setelah kegiatan" dengan 2 indikator.

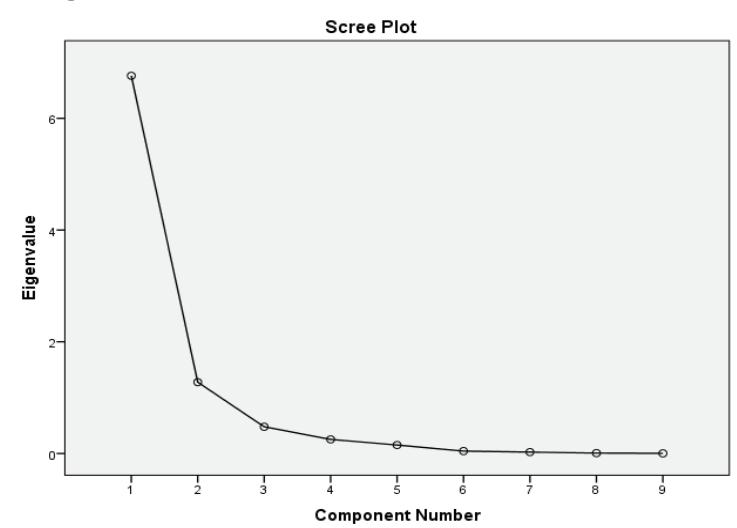

Gambar 6.

Garis Sumbu Component Number 1-9

Faktor Berdo'a Anak Usia 4-5 Tahun

Angka factor loading sebesar 0.550 merupakan cut off penerimaan indikator sebagai anggota faktor. Sub-faktor berdo'a setelah kegiatan terdiri dari indikator berdo'a syukur dibei guru dengan skor factor loading sebesar 0.881, do'a bersyukur diberi teman dengan skor factor loading sebesar 0.897, mengucapkan pujian kepada Tuhan dengan skor factor loading sebesar 0.913, berdo'a pasrah terhadap musibah dengan skor factor loading sebesar 0.872 , do'a permohonan ampunan atas kesalahan dengan skor factor loading sebesar 0.843, do'a setelah belajar dengan skor factor loading sebesar 0.931, dan do'a setelah makan dengan skor factor loading sebesar 0.913. Sedangkan sub-faktor berdo'a sebelum kegiatan terdiri dari dua indikator, yaitu berdo'a sebelum belajar dengan skor factor loading sebesar 0.957, dan berdo'a sebelum makan dengan skor factor loading sebesar 0.935 .

Faktor interaksi pembelajaran memiliki 11 indikator. Indikator membantu guru memperoleh skor communalities sebesar 0.756. Indikator membantu teman memperoleh skor communalities sebesar 0.650. Indikator berucap terima kasih memperoleh skor communalities sebesar 0.747. Indikator berucap mohon maaf memperoleh skor communalities sebesar 0.724. Indikator membalas sapaan teman memperoleh skor communalities sebesar 0.668. Indikator membalas sapaan guru memperoleh skor communalities sebesar 0.616. Indikator menyapa teman pada saat awal bertemu memperoleh skor communalities sebesar 0.760 . Indikator menyapa teman saat berpisah memperoleh skor communalities sebesar 0.764 . Indikator menyapa guru pada saat awal bertemu memperoleh skor communalities sebesar 0.861 . Indikator menyapa guru saat berpisah memperoleh skor communalities sebesar 0.634. Indikator praktik 1 memperoleh skor communalities sebesar 0.352. Masing-masing indikator tersebut memiliki skor communalities lebih besar dari 0.50 , kecuali untuk indikator praktik 1 memiliki skor di bawah 0.50 .

Ada sebelas komponen varians dari faktor interaksi pembelajaran. Apabila varians komponen 1 sampai dengan 
komponen 11 dijumlahkan, maka hasilnya sama dengan $11(7.533+0.885+0.665+$ $0.562+0.522+0.406+0.167+0.120+$ $0.063+0.041+0.035=11)$. Total variansnya juga berjumlah 11 , yaitu dari 11 komponen dikalikan total varians dari masing-masing komponen, yaitu 1 sehingga prosesnya menjadi $11 \times 1$. Komponen 1 memiliki skor Eigenvalues lebih besar dari 1 (7.533), sedangkan komponen 2, 3, 4, 5, 6, 7, 8, 9, 10, dan 11 memiliki skor Eigenvalues lebih kecil dari $1(0.885,0.665,0.562,0.522,0.406,0.167$, $0.120,0.063,0.041$, dan 0.035) maka proses factoring sudah selesai.

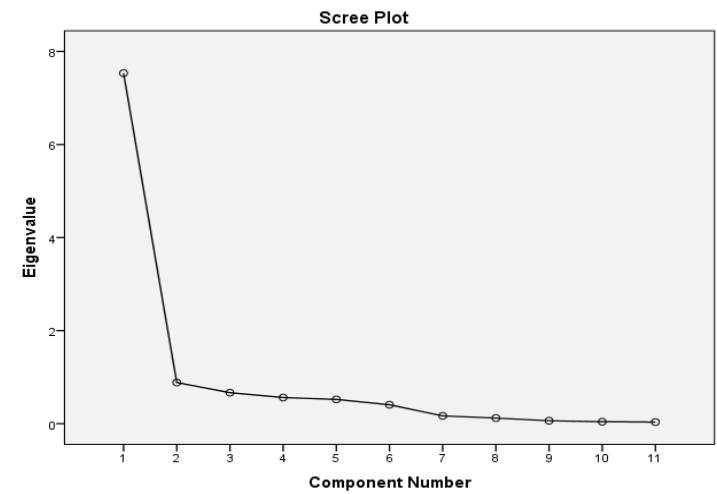

Gambar 7.

Garis Sumbu Component Number 1-11

Faktor Interaksi Pembelajaran Anak Usia 4-5 Tahun

Terlihat bahwa dari garis sumbu component number 1 ke 2 menurun tajam, tetapi dari komponen 2 ke 3, dari 3 ke 4, dari 4 ke 5, dari 5 ke 6 , dari 6 ke 7, dari 7 ke 8 , dari 8 ke 9, dari 9 ke 10, dan dari 10 ke 11 garis sumbu component number menurun landai. Skor Eigenvalues komponen 1 berada di atas skor Eigenvalues 1. Skor Eigenvalues komponen 2, 3, 4, 5, 6, 7, 8, 9, 10, dan 11 berada di bawah skor Eigenvalues 1 seperti pada Gambar 7. Hal ini menunjukkan bahwa kesebelas indikator dari faktor interaksi pembelajaran dapat dikumpulkan ke dalam satu faktor, yaitu interaksi pembelajaran anak usia 4-5 tahun.

Angka factor loading sebesar 0.550 merupakan cut off penerimaan indikator sebagai anggota faktor. Indikator membantu guru dengan skor factor loading sebesar 0.870, membantu teman dengan skor factor loading sebesar 0.806, berucap terima kasih dengan skor factor loading sebesar 0.865 , berucap mohon maaf dengan skor factor loading sebesar 0.851, membalas sapaan teman dengan skor factor loading sebesar 0.817, membalas sapaan guru dengan skor factor loading sebesar 0.785, menyapa teman pada saat awal bertemu dengan skor factor loading sebesar 0.872, menyapa teman saat berpisah dengan skor factor loading sebesar 0.874, menyapa guru saat awal berjumpa dengan skor factor loading sebesar 0.928 , menyapa guru saat berpisah dengan skor factor loading sebesar 0.796, dan praktik 1 dengan skor factor loading sebesar 0.594.

Kesebelas angka factor loading masing-masing indikator lebih besar dari skor $0.550(0.870,0.806,0.865,0.851$, $0.817,0.785,0.872,0.874,0.928,0.796$, dan 0.594) sehingga dapat disimpulkan bahwa faktor interaksi pembelajaran yang terdiri dari 11 indikator sudah mewakili perilaku nilai-nilai agama dan moral anak usia dini 4-5 tahun.

\section{SIMPULAN DAN SARAN Simpulan}

1. Ada 41 indikator teoretik perkembangan nilai-nilai agama dan moral untuk anak usia 5-6 tahun. Namun setelah proses confirmatory factor analyses berubah menjadi 27 indikator yang mengelompok pada 4 faktor, yaitu berdo'a, kebersihan diri, interaksi pembelajaran, dan pengetahuan/praktik beribadah. Ada satu faktor yang memiliki 3 sub-faktor, yaitu faktor interaksi pembelajaran mengelompok lagi menjadi sub-faktor tegur sapa, peduli, dan disiplin.

2. Ada 21 indikator teoretik perkembangan nilai-nilai agama dan moral untuk anak usia 4-5 tahun. Namun setelah proses confirmatory factor analyses berubah menjadi 20 indikator yang mengelompok pada 2 faktor, yaitu faktor berdo'a dan interaksi pembelajaran. Ada satu faktor yang memiliki 2 sub-faktor, 
yaitu berdo'a mengelompok lagi menjadi sub-faktor do'a sebelum kegiatan dan setelah kegiatan.

3. Ada 12 indikator teoretik perkembangan nilai-nilai agama dan moral untuk anak usia 3-4 tahun. Namun karena responden hanya berjumlah 9 anak (CFA mempersyaratkan minimal 20 subjek per butir) maka data tidak bisa dianalisis melalui proses confirmatory factor analyses. Solusinya data dianalisis berdasarkan kemunculan indikator teoretik pada perilaku anak yang diobservasi secara langsung. Setelah melalui pencermatan terhadap indikator instrumen ditemukanlah 10 indikator teoretik yang muncul dalam perilaku anak.

\section{Saran}

1. Ada 4 faktor perkembangan nilai-nilai agama dan moral untuk anak usia 5-6 tahun dengan jumlah indikator sebanyak 27 butir. Ada 2 faktor perkembangan nilai-nilai agama dan moral untuk anak usia 4-5 tahun dengan jumlah indikator sebanyak 20 butir. Ada 1 faktor perkembangan nilai-nilai agama dan moral untuk anak usia 3-4 tahun dengan jumlah indikator sebanyak 10 butir. Temuan ini dapat menjadi pintu masuk untuk melakukan uji lapangan ulang dengan jumlah responden lebih dari 100 anak.

2. Evaluasi ketercapaian standar isi PAUD perlu diperluas ke luar wilayah kota Yogyakarta.

\section{DAFTAR PUSTAKA}

Jalaludin Rakhmat. (2003). Psikologi agama sebuah pengantar. Bandung: Mizan.

Koentjaraningrat. (1986). Pengantar ilmu antropologi. Jakarta: Aksara Baru. Cetakan keenam.

Koentjaraningrat. (1987). Sejarah teori antropologi. Jakarta: Gramedia.
Jilid I.

Lickona, T. (1992). Educating for character: how our schools can teach respect and responsibility. New York: Bantam Books.

Menteri Pendidikan \& Kebudayaan RI. (2014). Peraturan menteri pendidikan dan kebudayaan nomor 137 tahun 2014 tentang standar isi pendidikan anak usia dini, lampiran satu tentang standar isi tingkat pencapaian perkembangan anak.

Menteri Pendidikan \& Kebudayaan RI. (2014). Peraturan menteri pendidikan dan kebudayaan nomor 146 tahun 2014 tentang kurikulum 2013 pendidikan anak usia dini, lampiran satu tentang kerangka dasar dan struktur kurikulum PAUD.

Menteri Pendidikan Nasional RI. (2009). Peraturan menteri pendidikan nasional nomor 58 tahun 2009 tentang standar pendididkan anak usia dini.

Singgih Santoso. (2014). Statistik multivariat. Jakarta: PT Elex Media Komputindo. 